Western North American Naturalist 70(4), (C) 2010, pp. 553-561

\title{
THE STREAM-LAKE ECOTONE: POTENTIAL HABITAT FOR JUVENILE ENDANGERED JUNE SUCKERS (CHASMISTES LIORUS)
}

\author{
Russell B. Rader ${ }^{1,3}$, Mark C. Belk ${ }^{1}$, Rollin Hotchkiss ${ }^{2}$, and Jaron Brown²
}

\begin{abstract}
Potamodromous fish are poorly studied even though they are threatened often by human activities. The June sucker (Chasmistes liorus) is an endangered potamodromous species endemic to Utah Lake. Larval June suckers have not been collected from Utah Lake for at least 3 decades. Recruitment appears to be limited by low temperatures and scarce food, resulting in mass starvation of larval June suckers in the stream environment. We compared water temperature, zooplankton food availability, and small fish abundance in the stream and in 3 habitats along the stream-lake ecotone (dense emergent vegetation, sparse emergent vegetation, and open lake) to test the hypothesis that all 3 factors would reach a maximum in the dense emergent vegetation of the stream-lake ecotone. We used the abundance of fathead minnows in each habitat type as a surrogate for small fish like juvenile June suckers. We found that temperature, food, and fathead minnows reached their maximums in the open lake rather than in vegetated habitats of the streamlake ecotone. The stream had the lowest average temperatures $\left(15.1^{\circ} \mathrm{C}\right)$ and the lowest zooplankton concentrations $\left(61 \cdot \mathrm{L}^{-1}\right)$ over the growing season. Contrary to expectations, low temperatures $\left(16.9^{\circ} \mathrm{C}\right)$ and low food abundance $\left(505 \cdot \mathrm{L}^{-1}\right)$ also characterized the densely vegetated habitat, whereas the open lake had the highest temperatures $\left(20.4^{\circ} \mathrm{C}\right)$ and highest concentrations of zooplankton $\left(2353 \cdot \mathrm{L}^{-1}\right)$. Restoration should include a mechanism to transport larval fish through the densely vegetated portion of the stream-lake ecotone, which can be hundreds of meters wide, to the warm productive waters of the open lake. The braided planform of the terminal reaches of Hobble Creek should be replaced with shallow riffles to increase mean stream velocity and decrease the transport time of larval June suckers.
\end{abstract}

Key words: stream-lake ecotone, juvenile fish habitat, June sucker.

RESUMEN. - Los peces potamodromos se han estudiado poco a pesar de que a menudo los amenazan las actividades humanas. El matalote junio (Chasmistes liorus) es una especie potamodroma en peligro de extinción que es endémica del Lago Utah. Hace al menos tres décadas que no se colectan matalotes larvales del Lago Utah. El reclutamiento parece estar limitado tanto por las temperaturas bajas como por la escasez de alimento, la cual causa una inanición masiva de matalotes junio larvales en el hábitat fluvial. Comparamos la temperatura del agua, disponibilidad de zooplancton y abundancia de peces pequeños en el arroyo y en tres hábitats a lo largo del ecotono arroyo-lago (vegetación semisumergida tupida, vegetación semisumergida escasa y el lago abierto) para comprobar la hipótesis de que los tres factores alcanzarían su máximo en la vegetación semisumergida tupida del ecotono arroyo-lago. Utilizamos la abundancia de la carpita cabezona en cada clase de hábitat como indicador indirecto de peces pequeños como los matalotes junio juveniles. Descubrimos que la temperatura, el alimento y las carpitas cabezonas alcanzaron sus niveles máximos en el lago abierto y no en los hábitats con vegetación del ecotono arroyo-lago. El arroyo tuvo las temperaturas promedio más bajas durante la temporada de crecimiento $\left(15.1^{\circ} \mathrm{C}\right)$ y concentraciones bajas de zooplancton $\left(61 \cdot \mathrm{L}^{-1}\right)$. Al contrario de lo esperado, el hábitat de vegetación tupida tuvo temperaturas bajas $\left(16.9^{\circ} \mathrm{C}\right)$ y concentraciones bajas de alimento $\left(505 \cdot \mathrm{L}^{-1}\right)$, mientras que el lago abierto tuvo la temperatura más alta $\left(20.4^{\circ} \mathrm{C}\right)$ y la mayor concentración de zooplancton $\left(2353 \cdot \mathrm{L}^{-1}\right)$. La restauración de esta especie debe incluir algún mecanismo para transportar los peces larvales a través de la parte de vegetación tupida del ecotono arroyo-lago, la cual puede tener cientos de metros de ancho, a las aguas cálidas y más productivas del lago abierto. Se debe reemplazar la forma trenzada de los tramos terminales de Hobble Creek con encalladeros para aumentar la velocidad promedio del arroyo y agilizar la travesía de los matalotes junio larvales.

Fish that migrate into rivers and streams from adjacent ecosystems are often at risk from human activities that block and fragment the lotic environment (e.g., Sheer and Steel 2006). For example, the effects of dams on the sustainability of anadromous salmon have been investigated extensively because of their economic importance (e.g., Ruckelshaus et al. 2002). However, many potamodromous fish are equally threatened (e.g., Scoppetone and Vinyard 1991) but poorly studied in comparison. Although we have a good understanding of the type of spawning habitats for many adult potamodromous fish (e.g., Chasmistes cujus Cui-ui,

${ }^{1}$ Department of Biology, Brigham Young University, Provo, UT 84602.

${ }^{2}$ Civil and Environmental Engineering, Brigham Young University, Provo, UT 84602

3E-mail: russell_rader@byu.edu 


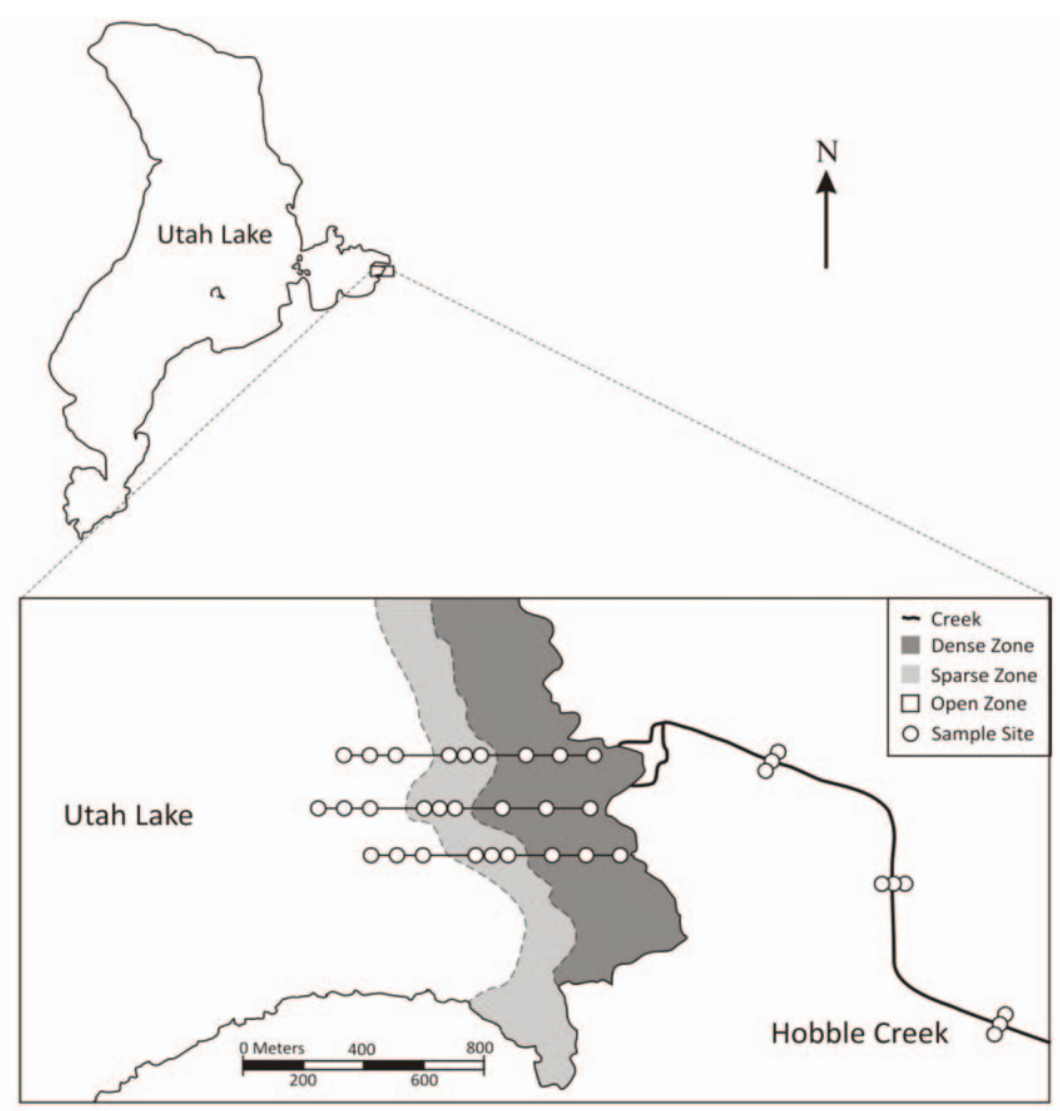

Fig. 1. Diagram showing study sites along 6 transects in 4 habitat types (creek, dense emergent vegetation, sparse emergent vegetation, and open lake) in Provo Bay and the Hobble Creek stream-lake ecotone.

Scoppetone et al. 1986; Chasmistes liorus June sucker, Andersen et al. 2007; Onchorhynchus clarki cutthroat trout, Gresswell et al. 1997), we often do not know the habitat requirements that best support juveniles returning to the lake from the riverine environment. The streamlake ecotone may be an important habitat for juvenile potamodromous fish because it could provide high temperatures, abundant food (e.g., zooplankton), and protection from predation (aquatic macrophytes).

Utah Lake is a large $\left(392 \mathrm{~km}^{2}\right)$, shallow (average approximately $2.7 \mathrm{~m}$ deep), eutrophic lake located in central Utah (Fig. 1). It is fed by numerous underground springs and 6 major tributaries. The June sucker (Chasmistes liorus) is an endangered species endemic to Utah Lake. Individuals in this population used to number in the millions (Jordan 1891), but the population has drastically declined over the last century (Radant and Sakaguchi 1981). Adults of this species spawn in tributaries with gravel-sized substrate, and larval fish drift downstream to mature in the lake (e.g., Shirley 1983). Historically, June suckers spawned in all major tributaries of the lake, but spawning is currently limited to Provo River (Modde and Muirhead 1994, Whitney and Belk 2000). Lack of recruitment is one of the main causes of population decline and endangerment (Sigler et al. 1985, USFWS 1999). Disruption of the natural hydrograph in Provo River combined with channelization of the lower reaches has changed the drift patterns of larval fish in the riverine environment (Modde and Muirhead 1994). Specifically, low temperatures and scarce food in the river appear to result in mass starvation of larval June suckers before they reach the stream-lake ecotone (Ellsworth et al. 2010).

Hobble Creek, a small tributary to Utah Lake, flows into Provo Bay (Fig. 1). Hobble Creek recently was selected as a location for 
restoration of a self-sustaining population of June suckers. Average historical peak flows $\left(4.4 \mathrm{~m}^{3} \cdot \mathrm{s}^{-1}\right)$ and base flows $\left(0.53 \mathrm{~m}^{3} \cdot \mathrm{s}^{-1}\right)$ in Hobble Creek, especially in the terminal section leading into Utah Lake, have been reduced by water development (Stamp et al. 2009). Discharge during the summer in the lower section of Hobble Creek $\left(0.02-0.41 \mathrm{~m}^{3} \cdot \mathrm{s}^{-1}\right.$, depending on drought conditions) is now often an order of magnitude lower than in predevelopment times (Stamp et al. 2009). Stream velocities are undoubtedly lower now than in predevelopment times because the channelized lower section of Hobble Creek has been filled with sediment and debris, producing multiple channels of slowmoving water. Thus, a reduced transport capacity may cause mass starvation of larval June suckers in the terminal reaches of Hobble Creek, similar to conditions in Provo River. The first phase of the Hobble Creek restoration, designed to enhance June sucker recruitment, began in 2008 and was completed in 2009. We provide background data (data from before restoration activities began) on temperature and food for larval June suckers in 4 habitats along the stream-lake ecotone of Hobble Creek: riverine environment, dense vegetation of the lake littoral habitat, sparse vegetation of the lake littoral habitat, and the open lake.

The objective of this study was to determine the habitat suitability for larval June suckers along the stream-lake ecotone of Hobble Creek. Specifically, we tested the hypothesis that warm temperatures, abundance of zooplankton, and abundance of the fathead minnow (Pimephales promelas) — a surrogate for small fish like juvenile June suckers-would correspond across the gradient, with each reaching a maximum in the densely vegetated portion of the ecotone. We hypothesized that this ecotone would provide warm water and zooplankton from the lake, nutrients from the stream (e.g., organic matter), and cover from predators, thus providing the best habitat for juvenile June suckers.

\section{Methods}

\section{Study Sites}

The stream-lake ecotone is the area at the mouth of a stream and the littoral zone of a lake where stream water mixes with lake water, creating a dynamic zone with potentially steep environmental gradients (Turner and Rao 1990, MacKenzie and Kaster 2004). Snowpack and lake levels were near their annual average during the course of this study (spring and summer of 2006). Thus, the stream-lake ecotone included the vegetated littoral zone of the lake. This may not always be the case. For example, during drought conditions lake levels may recede and the stream-lake ecotone may occur toward the center of Provo Bay, hundreds of meters from the vegetated littoral zone. Small fish and zooplankton were collected from 3 sites in each of 4 habitat types: (1) the lower stream channel of Hobble Creek, (2) dense emergent vegetation in the stream-lake ecotone $\left(>20\right.$ stems $\left.\cdot \mathrm{m}^{-2}\right)$, (3) sparse emergent vegetation in the stream-lake ecotone (1-15 stems $\cdot \mathrm{m}^{-2}$ ), and (4) the open lake (see Fig. 1 for all sampling locations). Samples were collected during the last 2 weeks of June and again in the month of August.

We divided lower Hobble Creek into 3 segments of equal length (upper, middle, and lower) starting about $1 \mathrm{~km}$ upstream from its confluence with Provo Bay and Utah Lake (Fig. 1). We divided the length of each segment into $10-\mathrm{m}$ sections and randomly selected one section to sample within each segment. We collected small fish and zooplankton samples at 3 sites located one-quarter, one-half, and three-quarters across the width of the stream in each section.

Three evenly spaced transects also extended perpendicular from the shore through the stream-lake ecotone, which was divided into 2 habitats: dense emergent vegetation and sparse emergent vegetation (Fig. 1). Small fish and zooplankton were collected at 3 sites separated by at least $50 \mathrm{~m}$ within each habitat type (dense vegetation, sparse vegetation, and open water). At each site in the dense and sparse vegetation habitats, 5 replicates, marked by a floating quadrat $\left(1 \mathrm{~m}^{2}\right.$ of a 0.75 -inch-diameter PVC pipe) were used to quantify the density of emergent vegetation. We chose the replicate location by haphazardly tossing half the quadrat in a random direction into the vegation and then connecting the other half before counting the number of stems emerging from the soil-water interface. Water depth along our transects in Provo Bay ranged from $0.6 \mathrm{~m}$ to $1.2 \mathrm{~m}$ at the start of this study. A handheld GPS unit was used to relocate the same sites in August.

\section{Temperature}

Thermographs (StowAway ${ }^{\circledR}$, Onset Computer Corporation) were used to record water 
temperatures every 3 hours within each habitat along the stream-lake ecotone; the recordings were taken from the time most larval fish have returned to the lake environment (1 July) to the end of the growing season (30 October). Three thermographs were deployed at a depth of $30 \mathrm{~cm}$ along the northernmost transect in the middle of each habitat. Thirty centimeters was an approximate midpoint depth in the shallowest zone (dense emergent vegetation). Frequent spot data and continuous measurements collected during and after this study were used to characterize the temperature regime at the uppermost stream site (see Stamp et al. 2009). We calculated the mean temperature, maximum temperature, and number of degree days during the growing season for each habitat. Growth and maturation in fish is largely determined by thermal summation (e.g., Bardach and Bjorklund 1957), often calculated by summing the number of degree days or the daily mean temperatures above $0{ }^{\circ} \mathrm{C}$ (e.g., Ward 1985).

\section{Zooplankton}

Gut analyses have shown that juvenile June suckers preferentially feed on rotifers (e.g., Brachionus spp.), small cladocerans (e.g., Bosmina spp.), and small copepods (Kreitzer et al. 2010). Vertical tows were used to collect zooplankton at each site. This method consists of drawing a circular net (64- $\mu \mathrm{m}$ mesh) through the water column from the bottom to the surface. Zooplankton density (number of individuals per liter) was based on the depth of a tow multiplied by the area of the net opening $\left(450 \mathrm{~cm}^{2}\right)$. A clear Plexiglas tube $(6.5 \mathrm{~cm}$ diameter, $60 \mathrm{~cm}$ long) was inserted vertically through the water column, capped on both ends, and poured through a $64-\mu \mathrm{m}$ mesh to estimate zooplankton densities in dense vegetation where plankton tows were not possible. All zooplankton samples were preserved in $95 \%$ ethanol in $500-\mathrm{mL}$ Whirlpak ${ }^{\circledR}$ bags.

In the laboratory, each sample was rinsed through a $64-\mu \mathrm{m}$ sieve, washed into a $100-\mathrm{mL}$ beaker of water, and shaken before extraction of five 2-mL subsamples. Individual taxa were viewed under a compound microscope (100X magnification) and enumerated using a stripcount technique (Wetzel and Likens 1991). The total count for each taxon in a sample was estimated as the sum of the 5 subsamples multiplied by 10 . The total count was converted to numbers per liter by dividing by the volume of lake water filtered in each sample. The density of zooplankton for each habitat (stream, dense emergent vegetation, sparse emergent vegetation, and open lake) on both dates was the mean of 9 replicate sites ( 3 sites along each of 3 transects in each habitat). A coarse taxonomic resolution (i.e., Rotifera, Cladocera, Copepoda, and Ostracoda) was sufficient to determine food availability for June suckers.

\section{Fathead Minnows}

We used fathead minnows as a surrogate for juvenile June suckers, which have not been collected from Utah Lake in the 30 years prior to this study (Radant and Sakaguchi 1981). Fathead minnows are the best surrogate because they are similar in size and shape to juvenile June suckers, and they lack spiny finrays like juvenile June suckers and thus face the same suite of predators. Fathead minnows are the only abundant species with such characteristics currently in the lake. The density of fathead minnows was estimated during the last week of August in each habitat using cylindrical minnow traps (length $40 \mathrm{~cm}$, diameter $30 \mathrm{~cm}$, opening $7 \mathrm{~cm}$ ). Four traps $(2$ at the surface and 2 near the bottom) were positioned along each transect at 2 of the 3 sites used for collecting zooplankton in each habitat (6 sites and 24 traps per habitat). Four minnow traps were also placed along the edge of the channel in each of the 3 creek sections. The number of fathead minnows in each trap was the average of two 24-hour periods at each site.

\section{Data Analysis}

We used a mixed-model analysis of variance (ANOVA) to determine differences between habitat types in the abundance of dominant zooplankton taxa and fathead minnows. Zooplankton and fathead minnow counts were natural-log transformed to meet parametric assumptions of normality and equal variances. We also used the unstructured option because we had no a priori expectation of a covariance structure. Month and habitat were considered fixed effects, and transects were treated as random effects in the zooplankton analysis (Proc MIXED, SAS Institute, Inc. 1997). Fathead minnows were only sampled during August, so the analysis only included habitat as a fixed effect and transects as a random effect. 
TABLE 1. Monthly mean and maximum (in parentheses) temperatures $\left({ }^{\circ} \mathrm{C}\right)$ and number of degree days (in brackets) in each habitat. A dash indicates insufficient data.

\begin{tabular}{lcccc}
\hline Month & Creek & Dense vegetation & Sparse vegetation & Open lake \\
\hline July & 21.3 & 24.3 & 26.5 & 26.6 \\
& $(26.1)$ & $(28.0)$ & $(30.4)$ & {$[30.7)$} \\
\multirow{3}{*}{ August } & {$[-]$} & {$[752]$} & {$[817]$} & {$[809]$} \\
& 18.2 & 20.5 & 23.7 & 23.5 \\
& $(22.3)$ & $(23.6)$ & $(27.6)$ & $(26.5)$ \\
September & {$[-]$} & {$[637]$} & {$[742]$} & {$[715]$} \\
& 12.9 & 13.5 & 16.4 & 18.8 \\
\multirow{3}{*}{ October } & $(17.6)$ & $(19.3)$ & $(21.7)$ & $(26.3)$ \\
& {$[-]$} & {$[411]$} & {$[490]$} & {$[539]$} \\
& - & $(13.6)$ & $(16.8$ & $(19.6$ \\
& {$[-$} & {$[274]$} & {$[345]$} & {$[375]$} \\
\hline
\end{tabular}

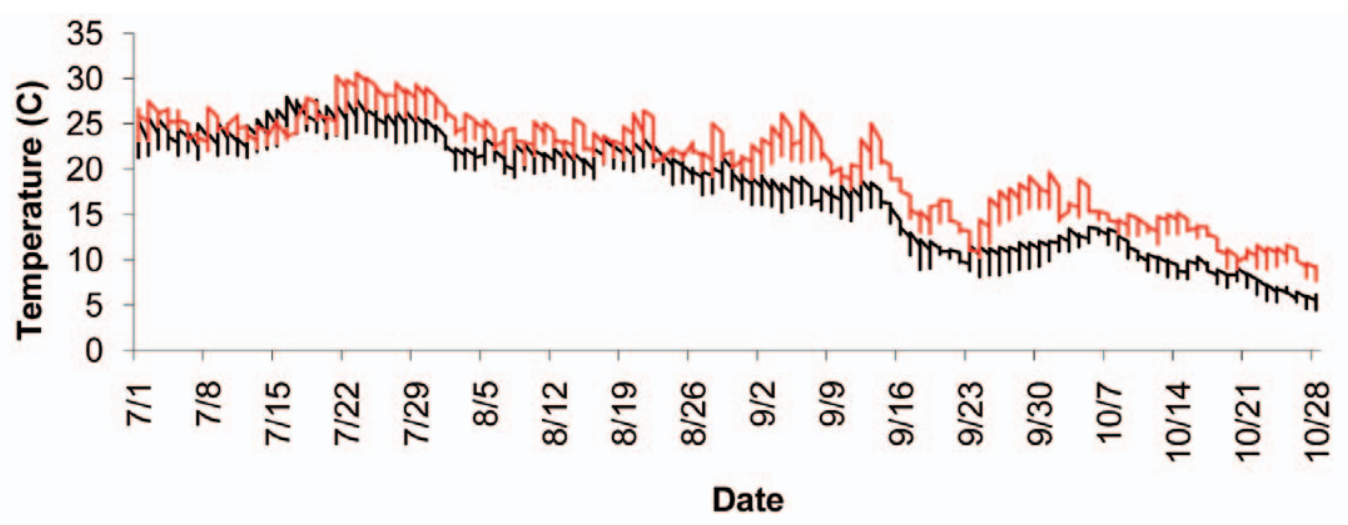

Fig. 2. Water temperatures in open lake (red line) versus dense emergent vegetation (black line). Vertical lines show the daily range. Horizontal trend lines connect the last temperature of the previous day to the first temperature of the next day.

\section{RESULTS}

\section{Temperature}

The open lake and sparse vegetation zones were the warmest habitats, especially during September and October (Table 1, Fig. 2). The dense vegetation habitat was on average $2-4^{\circ} \mathrm{C}$ cooler than either the open lake or the sparse vegetation zone probably because of shading by emergent vegetation (Fig. 2). The number of degree days was consistently between 50 and 100 greater in the sparse and open habitats than in the dense emergent vegetation (Table 1). Overall, the total number of degree days summed across the growing season (1 July-30 October) in the open lake (2438 degree days, ${ }^{\circ} \mathrm{C}$ ) was 364 degree days greater than in the dense emergent vegetation (2074 degree days).
Surprisingly, stream temperatures (mean, minimum, and maximum) were only $3-5{ }^{\circ} \mathrm{C}$ cooler during July and August in Hobble Creek compared to any of the lake habitats (Table 1). Although Hobble Creek is a typical cold mountain stream, there are at least 3 run-of-the-river diversions between the canyon and the lake that form surface-release impoundments that increase temperatures to downstream reaches.

\section{Zooplankton}

There was considerable variation in the density of zooplankton across months and habitats in the stream-lake ecotone. However, some patterns were obvious. There was low zooplankton abundance in the creek, and greater zooplankton abundance in the open habitat (Fig. 3). Rotifers were the most abundant group 


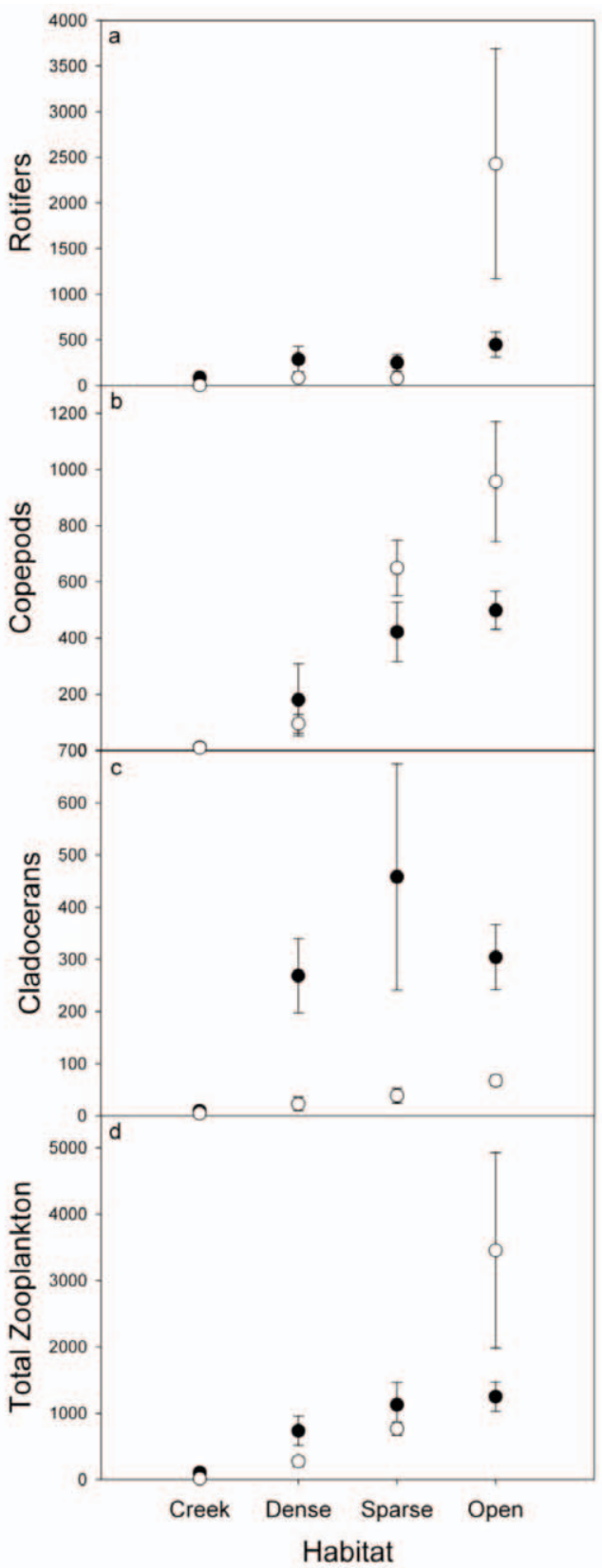

Fig. 3. Density of zooplankton (number per liter) in different habitats (creek, dense emergent vegetation, sparse emergent vegetation, and open lake) during June (closed circles) and August (open circles) 2006. Vertical bars represent one standard error.

of zooplankton. Their densities differed by habitat type $\left(F_{3,60}=20.7, P<0.0001\right)$, and their greatest abundance was in the open lake, especially in August (Fig. 3a). Rotifer densities

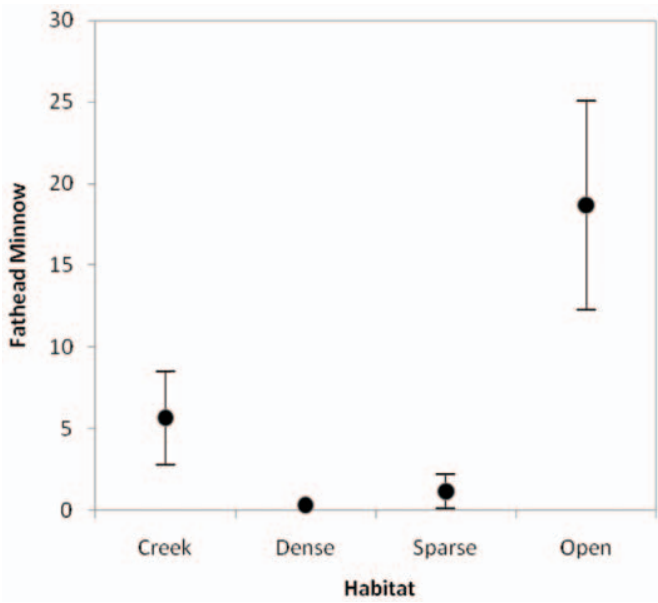

Fig. 4. Fathead minnow densities (number per trap) in different habitats (creek, dense emergent vegetation, sparse emergent vegetation, and open lake) during August 2006. Vertical bars represent one standard error.

did not differ by month $\left(F_{1,60}=2.03, P=0.16\right)$, and the habitat $\times$ month interaction was not significant $\left(F_{3,60}=1.58, P=0.2\right)$. Like rotifers, the abundance of copepods also varied by habitat type $\left(F_{360}=15.73, P<0.0001\right)$ but not by month $\left(F_{1,60}=0.4, P=0.53\right)$, and the habitat $\times$ month interaction was not significant $\left(F_{3,60}=0.02, P=0.99\right)$. Copepods also achieved their greatest densities in the open lake and sparsely vegetated habitat (Fig. 3b). Cladoceran densities differed by habitat type $\left(F_{3,60}=13.43, P<0.0001\right)$ and by month $\left(F_{1,60}=7.7, P=0.007\right)$, but the habitat $\times$ month interaction was not significant $\left(F_{3,60}=\right.$ 1.67, $P=0.18)$. Cladoceran densities were greatest in June and similarly high in both vegetated habitats and the open lake (Fig. 3c).

\section{Fathead Minnows}

Fathead minnows were most abundant in the open lake, showed low densities in the creek, and were rare in sparse and dense vegetation littoral habitats $\left(F_{3,17}=4.25, P=0.02\right.$; Fig. 4). Every trap in the open lake contained fathead minnows, whereas, in the vegetated habitats, fathead minnows were absent in all but 2 traps.

\section{Discussion}

High temperatures, food availability, and fathead minnow abundances did correspond across 
the stream-lake ecotone consistent with our hypothesis. Contrary to our hypothesis, however, all 3 attributes reached their maximum values in the open lake rather than in the vegetated habitats (dense or sparse). Thus, these results indicate that the best habitat for juvenile June suckers is the open lake because of high temperatures and abundant food. However, lethal water temperatures are frequently only a few degrees above optimum temperatures for growth and maturation (Brock 1985). Maximum water temperatures in the sparse and open habitats did occasionally exceed the chronic level lethal to June suckers (approximately 28 ${ }^{\circ} \mathrm{C}$ ) but only for 4-5 hours during the warmest days in July. Kindschi et al. (2005) found that temperatures that remained at or near $28{ }^{\circ} \mathrm{C}$ for 60 days were required to induce death. Thus, open water provides the highest temperatures for growth and maturation without exceeding lethal temperatures for June suckers.

Although some studies have shown that zooplankton abundance can be greater in dense emergent stands compared to open lake habitats because dense stands provide a refuge from fish predation (e.g., Genkai-Kato 2007), our results show the opposite pattern. The densely vegetated habitat was cooler than the open lake and contained much less zooplankton food than the open-water habitat. Emergent macrophytes can increase the settling of nonfloating phytoplankton species (e.g., Van den Berg et al. 1997) and reduce nutrient availability (Genkai-Kato and Carpenter 2005) causing a reduction in phytoplankton which often results in a reduction of filter-feeding zooplankton (e.g., Scheffer 1998). Previous studies have shown how temperature and phytoplankton decline and water clarity increases because of shading effects, reduced wave action, increased sediment stability, and reduced phosphorus recycling from lake sediments where rooted macrophytes (emergent and submerged) are abundant (Jeppesen et al. 1990, 1997, Scheffer 1998, Genkai-Kato and Carpenter 2005). These effects of emergent macrophytes on food availability and temperature are most intensely manifest toward the center of large dense stands. The margins of emergent stands and submersed macrophyte beds may provide a refuge from predation for juvenile June suckers while providing access to food in the open lake.

Our results support previous hypotheses explaining recruitment failure of potamodromous fish in Utah Lake (Ellsworth et al. 2010). That is, water extraction and diminished channel capacity have decreased discharge and current velocities, causing an increase in the residence time of larval fish in the stream environment and resulting in catastrophic death by starvation. The terminal section of Hobble Creek had lower temperatures and very little food. Historically, unregulated flows during spring runoff would have rapidly transported larval fish into the open lake, which had abundant food and higher temperatures. Under present conditions, the residence time of larval fish in the stream environment will depend on restoring some component of historical flows (e.g., peak spring flows during June).

\section{Inferences for Restoration}

To restore conditions more conducive to the recruitment of young June suckers, the sedimented and distributary planform of the terminal stream reaches entering Utah Lake should be replaced with shallow riffles to increase mean stream velocity and thus decrease the transport time of larval June suckers. In addition, restoration should include some mechanism to transport larval fish through the densely vegetated portion of the stream-lake ecotone-which can be hundreds of meters wide-to the warm productive waters of the open lake. Either the flow of Hobble Creek must transport larval fish through the densely vegetated habitats, or the width of this habitat must be decreased to bring the open lake closer to the mouth of Hobble Creek. Both may be necessary during drought conditions when stream flows have decreased and lake levels have receded.

Finally, to maximize June sucker recruitment, restoration of Hobble Creek should be coupled with restoration of Utah Lake. Small fish of many species forage along the margins of vegetation patches (e.g., submersed macrophytes), which provide a refuge from predation (e.g., Mittelbach 1986, 1988). Historically, patches of submersed macrophytes, especially Potamogeton spp., may have been common in the shallow, open water of Provo Bay. Introduced common carp (Cyprinus carpio) have likely reduced submersed vegetation in Utah Lake. The detrimental effects of carp on submersed vegetation in shallow lakes have been unequivocally demonstrated in a variety of studies around the world (Threinen and Helm 1954, Tryon 1954, King and Hunt 1967, Crivelli 1983). Generally, 
carp removal in small lakes has resulted in vegetation recovery and increased water clarity (Rose and Moen 1952, Cahoon 1953, Threinen and Helm 1954). In 2008, state agencies embarked on an ambitious plan to reduce common carp abundance in Utah Lake. If successful, this endeavor should increase the amount of vegetation and thus the area of refuge habitat for juvenile June suckers. However, our data show that zooplankton food may also be lower within these patches compared to the open lake. However, reduced food availability and increased water clarity across Provo Bay and Utah Lake is not a likely outcome of carp reduction in this system. Increased patches of submersed vegetation would likely represent an incremental step toward a clear-water state, but high turbidity and zooplankton food availability would continue throughout much of the system. Frequent wind-driven wave action would continue to stir nutrients and silt-sized calcite particles throughout the water column, especially in open water between macrophyte patches. Thus, the combination of stream restoration and carp removal could increase recruitment of larval June suckers by increasing transportation rates to the open lake where the suckers would find warm temperatures, high food abundance, and refuge from predation in the edges of macrophyte patches.

\section{ACKNOWLEDGMENTS}

The authors acknowledge the Utah Center for Water Resources Research and the Brigham Young University Office of Research and Creative Activities for their support of this project. Undergraduate students Jaron Brown, John Aedo, Tammy Thompson, and Shawn Stanley assisted with the fieldwork and data collection.

\section{Literature Cited}

Andersen, M.E., C.J. Keleher, J.E. Rasmussen, E.S. Hansen, P.D. Thompson, D.W. Speas, M.D. RoutLEDGE, AND T.N. HEDRICK. 2007. Status of June sucker in Utah Lake and refuges. Pages 39-58 in M.J. Brouder and J.A. Scheurer, editors. Status, distribution, and conservation of native freshwater fishes of western North America: a symposium proceedings. American Fisheries Society, Bethesda, MD.

BARDACH, J.E., AND R.G. BJORKLUND. 1957. The temperature sensitivity of some American freshwater fishes. American Naturalist 91:233-252.

Bвоск, T.D. 1985. Life at high temperatures. Science 230:132-138.
Cahoon, W.G. 1953. Commercial carp removal at Lake Mattamuskeet, North Carolina. Journal of Wildlife Management 17:312-316.

CrivelLi, A.J. 1983. The destruction of aquatic vegetation by carp Cyprinus carpio a comparison between southern France and the USA. Hydrobiologia 106:37-42.

Ellsworth, C.M., M.C. BelK, AND C.J. Keleher. 2010. Residence time and drift patterns of larval June sucker Chasmistes liorus in the lower Provo River as determined by otolith microstructure. Journal of Fish Biology 77:526-537.

GENKAI-KATO, M. 2007. Macrophyte refuges, prey behavior and trophic interactions: consequences for lake water clarity. Ecology Letters 10:105-114.

GENKAI-Kato, M., AND S.R. CARPENTER. 2005. Eutrophication due to phosphorus recycling in relation to lake morphometry, temperature, and macrophytes. Ecology $86: 210-219$.

Gresswell, R.E., W.J. Liss, G.L. LaRson, and P.J. BarTLEIN. 1997. Influence of basin-scale physical variables on life history characteristics of cutthroat trout in Yellowstone Lake. North American Journal of Fisheries Management 17:1046-1064.

Jepresen, E., J.P. Jensen, P. Kristensen, M. Søndergaard, E. Mortensen, O. SortkjÆr, and K. Olrik. 1990. Fish manipulation as a lake restoration tool in shallow eutrophic, temperate lakes 2: threshold levels, longterm stability and conclusions. Hydrobiologia 200/ 201:219-228.

Jeppesen, E., M. Søndergaard, J.P. Jensen, E. Kanstrup, And B. Petersen. 1997. Macrophytes and turbidity in brackish lakes, with special emphasis on the role of top-down control. Pages 369-377 in E. Jeppesen, M. Søndergaard, and K. Kristoffersen, editors, The structuring role of submerged macrophytes in lakes. Springer Verlag, New York, NY.

JoRDAN, D.S. 1891. Report of exploration in Colorado and Utah during the summer of 1889, with an account of the fishes found in each of the river basins examined. United States Fisheries Commission Bulletin 9:1-40.

Kindschi, G.A., M. Toner, W.C. Fraser, M.D. RoutLedge, M. Wilson, And Y. Converse. 2005. June Sucker Recovery Program summary progress report: task 3: evaluation of thermal requirements for June sucker propagation. Project Number V.05.02. 15 pp.

KING, D.R., AND G.S. HunT. 1967. Effect of carp on vegetation in Lake Erie Marsh. Journal of Wildlife Management 31:181-188.

Kreitzer, J.D., M.C. Belk, D.B. Gonzalez, R.C. TuckField, D.K. ShiozaWa, And J.E. Rasmussen. 2010. Ontogenetic diet shift in the June sucker Chasmistes liorus (Cypriniformes, Catostomidae) in the early juvenile stage. Ecology of Freshwater Fish 19:433438.

MacKenzie, R.A., AnD J.L. Kaster. 2004. Temporal and spatial patterns of insect emergence in a Lake Michigan coastal wetland. Wetlands 24:688-700.

Mittelbach, G.G. 1986. Predator-mediated habitat use: some consequences for species interactions. Environmental Biology of Fishes 16:159-169.

1988. Competition among refuging sunfishes and effects of fish density on littoral zone invertebrates. Ecology 69:614-623.

Modde, T., AND N. MuIRHEAD. 1994. Spawning chronology and larval emergence of June sucker (Chasmistes liorus). Great Basin Naturalist 54:366-370. 
RADANT, R.D., AND D.K. SAKaGUCHI. 1981. Utah Lake fisheries inventory. United States Bureau of Reclamation Contract 8-07-40-50634 Modification 04, Utah Division of Wildlife Resources, Salt Lake City, UT.

Rose, E.T., AND T. MoEn. 1952. The increase in game fish populations in east Okoboji Lake, Iowa, following intensive removal of rough fish. Transactions of the American Fisheries Society 82:104-114.

Ruckelshaus, M., P. Levin., J. Johnson, and P. Kareiva. 2002. The Pacific salmon wars: what science brings to the challenge of recovering species. Annual Review of Ecology and Systematics 33:665-706.

SAS InstituTE, Inc. 1997. SAS/STAT software: changes and enhancements through release 6.12. SAS Institute, Inc., Cary, NC.

Scheffer, M. 1998. Ecology of shallow lakes. Population and Community Biology Series 22, Kluwer Academic Publishers, Dordrecht, The Netherlands.

Scoppettone, G.G., M. Coleman, and G.A. Wedemeyer. 1986. Life history and status of the endangered Cui-ui (Chasmistes cujus) of Pyramid Lake, Nevada. U.S. Fish and Wildlife Service Research Report 1:1-23.

SCOPPETTONE G.G., AND G. VINYARD. 1991. Life history of four endangered lacustrine suckers. Pages 359-377 in M.L. Minckley, and J.E. Deacon, editors, Battle against extinction: native fish management in the American West. University of London Press, Tucson, AZ.

Sheer, M.B., AND E.A. STEEL. 2006. Lost watersheds: barriers, aquatic habitat connectivity, and salmon persistence in the Willamette and lower Columbia River basins. Transactions of the American Fisheries Society 135:1654-1669.

Shirley, D.L. 1983. Spawning ecology and larval development of the June sucker. Proceedings of the Bonneville Chapter, American Fisheries Society (1983): 18-36.

SigLER, W.F., S. VIGG, AND M. BREs. 1985. Life history of the cui-ui, Chasmistes cujus Cope, in Pyramid Lake, Nevada: a review. Great Basin Naturalist 45:571-603.
Stamp, M., T. Eddie, and D. Olsen. 2009. Lower Hobble Creek Ecosystem flow recommendations: draft report. BIO-WEST, Inc., Allred Restoration. 47 pp.

Threinen, C.W., And W.T. Helm. 1954. Experiments and observations designed to show carp destruction of aquatic vegetation. Journal of Wildlife Management 18:247-251.

Tryon, C.A.J. 1954. The effect of carp exclosures on growth of submerged aquatic vegetation in Pymaturing Lake, Pennsylvania. Journal of Wildlife Management 18:251-254

TuRner, R.A., AND Y.S. RAO. 1990. Relationships between wetland fragmentation and recent hydrologic changes on a deltaic coast. Estuaries 13:272-281.

[USFWS] U.S. Fish AND WILDLIFE SERVICE. 1999. June sucker (Chasmistes liorus) recovery plan. U.S. Fish and Wildlife Service, Denver, CO. $61 \mathrm{pp}$.

Van den Berg, M.S., H. Coops, M. Meijer, M. Scheffer, AND J. Simons. 1997. Clear water associated with dense Chara vegetation in the shallow and turbid Lake Veluwemeer, The Netherlands. Pages 339-352 in E. Jeppesen, M. Søndergaard, and K. Christoffersen, editors, The structuring role of submerged macrophytes in lakes. Springer-Verlag, New York, NY.

WARD, J.V. 1985. Thermal characteristics of running waters. Hydrobiologia 125:31-46.

WETZEL, R.G., AND G.E. LiKENS. 1991. Limnological analyses. 2nd edition. Springer-Verlag.

Whitney, M., AND M.C. BELK. 2000. Threatened fishes of the world: Chasmistes liorus Jordan, 1878 (Catostomidae). Environmental Biology of Fishes 57:362.

Received 14 December 2009 Accepted 6 August 2010 